\title{
Multifunctional Drug Treatment in Neurotrauma
}

\author{
Bogdan Stoica, Kimberly Byrnes, and Alan I. Faden \\ Department of Neuroscience, Georgetown University Medical Center, Washington, DC 20057
}

Summary: Although the concepts of secondary injury and neuroprotection after neurotrauma are experimentally well supported, clinical trials of neuroprotective agents in traumatic brain injury or spinal cord injury have been disappointing. Most strategies to date have used drugs directed toward a single pathophysiological mechanism that contributes to early necrotic cell death. Given these failures, recent research has increasingly focused on multifunctional (i.e., multipotential, plu- ripotential) agents that target multiple injury mechanisms, particularly those that occur later after the insult. Here we review two such approaches that show particular promise in experimental neurotrauma: cell cycle inhibitors and small cyclized peptides. Both show extended therapeutic windows for treatment and appear to share at least one important target. Key Words: Neurotrauma, neuroprotection, treatment, cell cycle inhibitors, small cyclized peptides.

\section{INTRODUCTION}

Trauma to the CNS causes both direct tissue damage and more delayed biochemical changes that lead to cell loss (secondary injury), demyelination, and related functional deficits. ${ }^{1}$ Initiation of such biochemical cascades occurs from minutes to weeks after the insult. Numerous factors associated with delayed tissue loss have been identified from experimental studies of traumatic brain injury (TBI) and spinal cord injury (SCI); these include products of lipid degradation, disrupted ionic homeostasis, altered neurotransmitter release and receptor function, and inflammatory and immune changes. ${ }^{1-3}$ Together, these biochemical and associated metabolic effects result in loss of neuronal and oligodendroglial cells, reactive astrogliosis, and proliferation/activation of microglia. $^{4,5}$

Most neuroprotective strategies have been directed at individual components of this delayed reactive cascade, such as reducing free radical-induced actions, excitotoxicity, or inflammation. Whereas many such strategies have proven effective in experimental animal models of TBI or SCI, they have shown little or no neuroprotective actions in humans. ${ }^{2}$ However, the majority of clinical neuroprotective approaches to date have been directed at reducing neuronal necrosis, which is a relatively early

Address correspondence and reprint requests to: Bogdan A. Stoica, M.D., Department of Neuroscience, Research Building, Room WG18, 3970 Reservoir Rd, NW, Georgetown University School of Medicine, Washington, DC 20057. E-mail: stoicab@georgetown.edu. event that is largely completed within 6 to 8 h. ${ }^{6}$ Yet only a relative minority of patients with neurotrauma can have treatment initiated within this time period. In addition, most therapies have aimed at modifying single components of the complex secondary injury cascade, even though it is recognized that many autodestructive biochemical changes occur in parallel. Use of multiple drug treatments, each directed to a different secondary injury component, has rarely been attempted (even experimentally) in neurotrauma, ${ }^{7}$ although multifactorial combination drug approaches have long been standard therapy for certain infectious diseases and cancers. However, even if such combination treatments showed promise in animal models, the methodological difficulties and costs associated with such multi-drug comparison studies in treating clinical neurotrauma would likely prove prohibitive.

An alternative approach would be to identify single agents that can modify diverse secondary injury cascades. A number of such multifunctional or multipotential treatments has been proposed and successfully tested in experimental neurotrauma models. These have included naturally occurring substances, such as thyrotropin-releasing hormone (TRH), progesterone, heat shock protein, neurotrophic factors, and erythropoietin; drugs developed for other disorders such as statins or antibiotics; and agents developed through rational drug design. $^{2}$

We have developed two multifunctional treatment approaches that have proved to be remarkably effective for the treatment of TBI and/or SCI. One was developed 
through a rational drug design program and was based on the tripeptide hormone TRH. The other has adapted drugs used extensively in experimental oncology with targets based on data developed from extensive genomics profiling in experimental TBI and SCI.

\section{TRH AND NOVEL TRH ANALOGUES}

In the early 1980s, we demonstrated that TRH, when used at higher than physiological concentrations, markedly improved outcome after experimental SCI, with a therapeutic window of at least $24 \mathrm{~h}^{8,9}$ TRH inhibits multiple secondary injury factors or processes, including declines of blood flow and bioenergetics, lipid degrada- tion products such as peptidyl leukotriene and platelet activating factor, ionic dyshomeostasis $(\mathrm{Na}+, \mathrm{K}+$, $\mathrm{Ca}++, \mathrm{Mg}++)$, endogenous opioids, and excitotoxins. ${ }^{10-12}$ Subsequently, we found that TRH analogues that modified either the N-terminal or the middle amino acid of the tri-peptide hormone pyroglutamyl-histidylprolineamide were even more effective than TRH, with longer biological half-lives and fewer undesirable physiological actions. Such analogues proved highly effective in improving functional recovery and reducing lesion volume after experimental SCI or TBI. ${ }^{13-17}$ The neuroprotective actions of TRH and TRH analogues in experimental neurotrauma have subsequently been confirmed

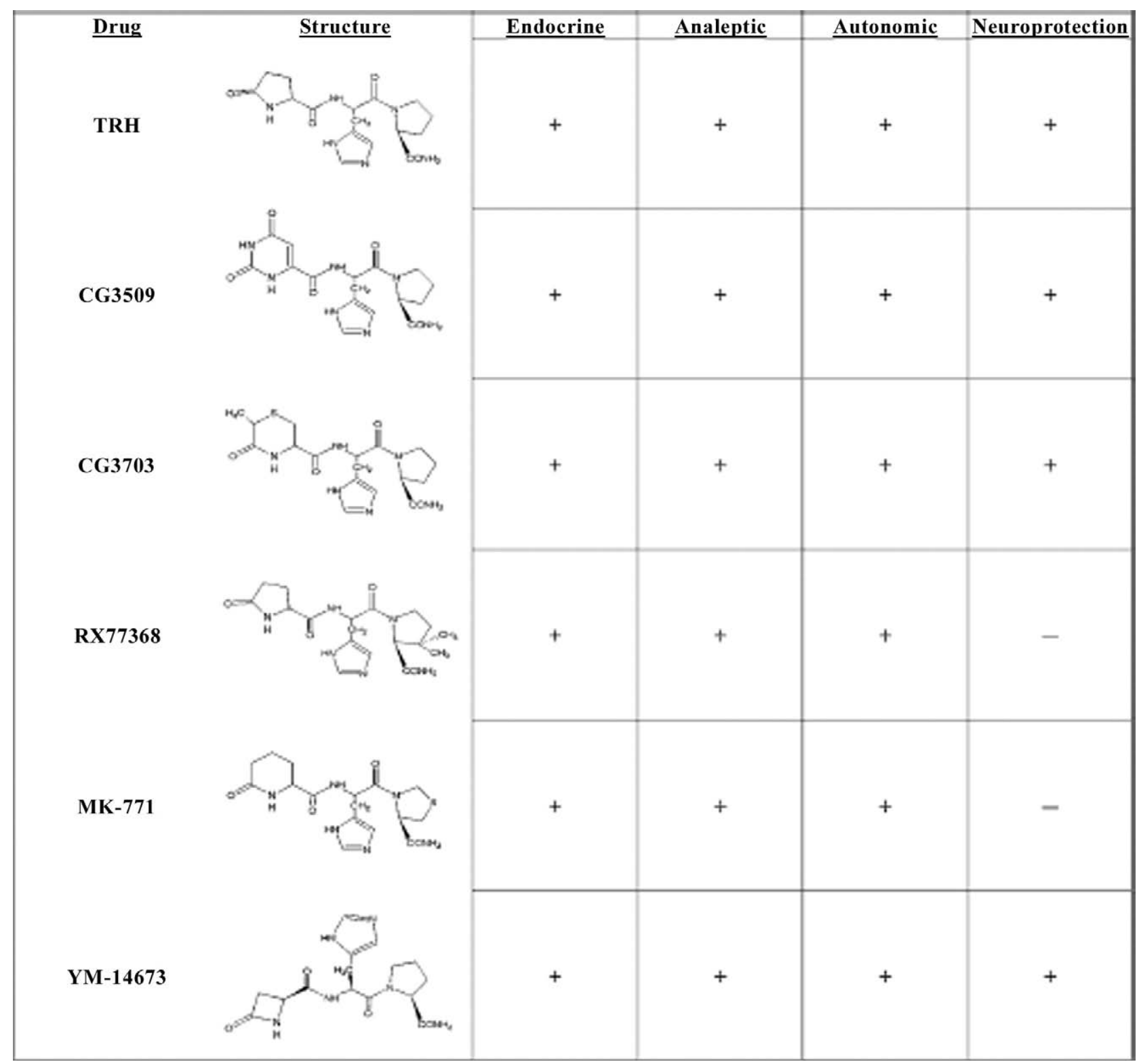

FIG. 1. Comparison of thyrotropin-releasing hormone (TRH) and various substituted TRH analogues that retain the endocrine, autonomic, and analeptic actions of TRH. Modifications of the N-terminus retain neuroprotective activity, whereas modifications of the C-terminus do not. +, positive effect; -, no effect. Reprinted with permission from Faden Al, et al. Ann NY Acad Sci 2005;1053:472-481. 
by many laboratories. ${ }^{18-22}$ Moreover, a small clinical trial of TRH suggested protective effects after SCI. ${ }^{23}$

TRH is metabolized through two major pathways: endopeptidase cleavage of pyroglutamyl to produce cyclohistidyly-proline diketopiperazine (CHP) or deamidation yielding the free acid form of TRH. ${ }^{24,25}$ Various TRH analogues have been developed that modify one of its amino acids (FIG. 1). ${ }^{26}$ Pyroglutamyl substitutions limit endopeptidase-mediated metabolism, resulting in compounds that have far longer biological half-lives than TRH (6-8 h vs $5 \mathrm{~min}$ ); some of these are also more potent than TRH in terms of CNS activity. For example, YM-14673 is longer acting than TRH (8-36 times) and much more potent (10-100 times). ${ }^{15}$ However, N-terminal substitutions retain the other physiological actions of TRH (i.e., endocrine, autonomic, and analeptic). We have also evaluated modifications of the histidyl residue (i.e., imidazole substitution); certain substitutions reduced the cardiovascular and/or endocrine activity while maintaining the neuroprotective actions of TRH (FIG. 2). ${ }^{27}$ Critically, modification of the C-terminus results in compounds devoid of neuroprotective activity, although they retain endocrine, autonomic, and analeptic activity similar to TRH.

Based on these observations, we developed dual-substituted TRH analogues (i.e., modifications at both the $\mathrm{N}$-terminal and histidyl moieties). Such compounds (53a, 57a) have limited endocrine, autonomic, and analeptic effects while preserving or enhancing the neuroprotective actions (FIG. 2) ${ }^{16,26}$ Compound 53a is at least two orders of magnitude more hydrophobic than either TRH or YM-14673, based on their partition coefficients between n-octanol and water $(\log \mathrm{P})$; thus it should have enhanced cellular permeability to the CNS. ${ }^{16}$

\section{CYCLIC DIPEPTIDES}

TRH is metabolized to a cyclic dipeptide (CHP), which, like other diketopiperazines, retains considerable physiological activity. ${ }^{28}$ We have developed a series of diketopiperazines structurally related to CHP (FIG. 3). ${ }^{29}$ One of these (35b) has been extensively examined using in vitro and in vivo model systems. ${ }^{29-32}$ In neuronal cell culture models, $35 \mathrm{~b}$ provides neuroprotection in necrotic

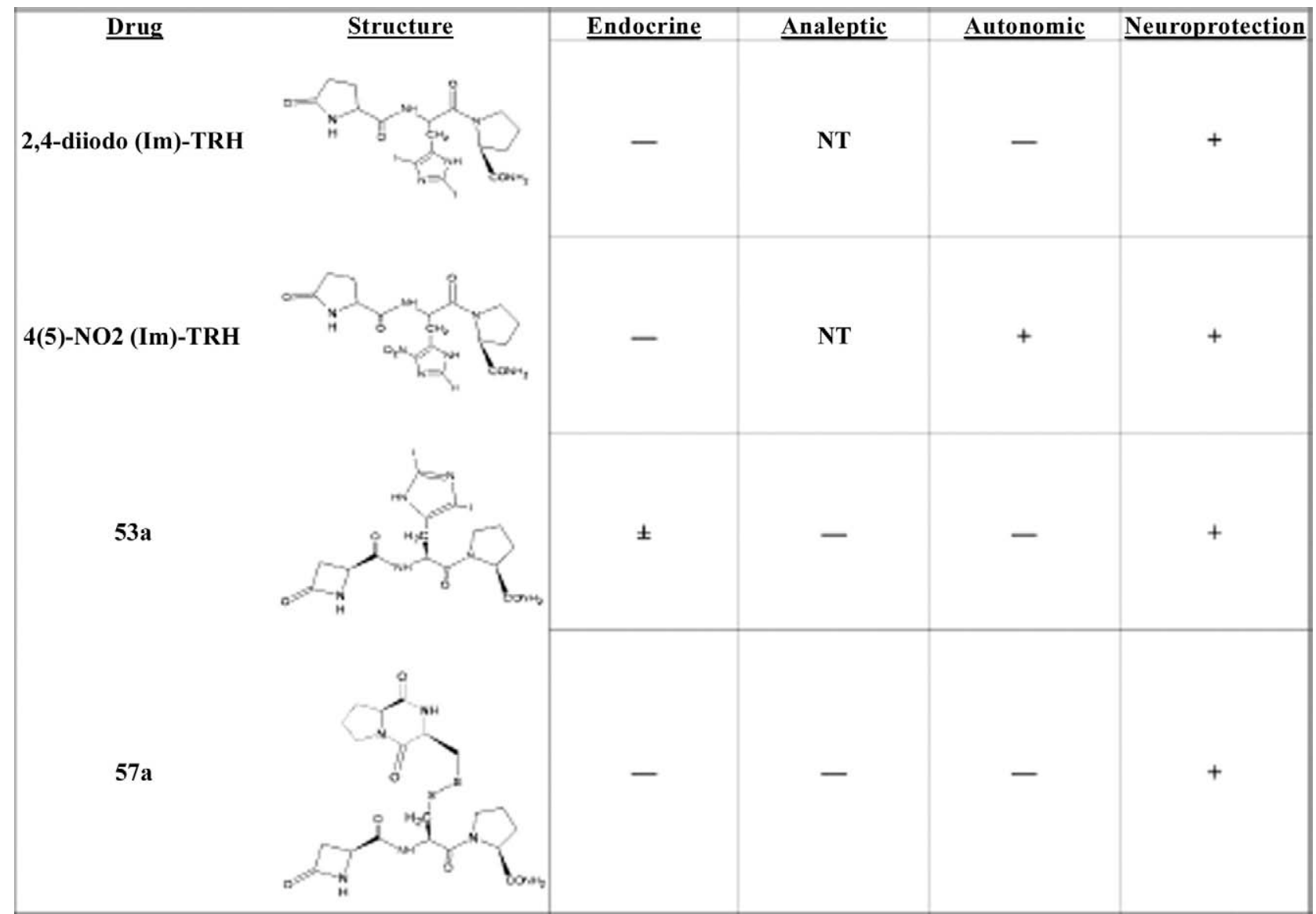

FIG. 2. Comparison of the physiological actions of novel thyrotropin-releasing hormone (TRH) analogues that modify the imidazole structure. These analogues retain neuroprotective activity, but show reduced or absent endocrine, analeptic, and/or autonomic actions. +, positive effect; -, no effect; \pm , partial effect; NT, not tested. Reprinted with permission from Faden Al, et al. Ann NY Acad Sci 2005;1053:472-481. 
$35 b$<smiles>O=C1NC2(CCCCC2)C(=O)N2CCC[C@H]12</smiles>

606<smiles>CC(C)(C)c1cc(C[C@@H]2NC(=O)[C@@H]3CCCN3C2=O)cc(C(C)(C)C)c1O</smiles>

FIG. 3. Chemical structures of the cyclic dipeptides 35b, 144 606 , and 807. Reprinted from Faden et al. Neuropharmacology 2005;49:410-424.

cell death models (i.e, maitotoxin, glutamate, mechanical injury), as well as in apoptotic cell death models (i.e., staurosporine, beta amyloid) (FIG. 4). ${ }^{31}$ Given intravenously, $35 \mathrm{~b}$ reduced lesion volume by nearly $70 \%$. It also improved functional (i.e., cognitive and motor) outcomes after either fluid percussion-induced traumatic brain injury (FPI) in rats or controlled cortical impact (CCI) injury in mice. ${ }^{30,31}$ Treatment also significantly reduced apoptotic cell death in rat hippocampus after FPI. The therapeutic window for the drug is at least $8 \mathrm{~h}$, and it shows a relatively flat dose response for neuroprotection between 0.1 and $10 \mathrm{mg} / \mathrm{kg}$. Optimal doses are between 1 and $3 \mathrm{mg} / \mathrm{kg}$, with repeated dosing over time showing no added benefit as compared to single bolus dose treatment. $35 \mathrm{~b}$ is currently being developed by RemeGenix, Inc., for clinical trials in head injury.

Using the NIMH Psychoactive Drug Screening Program, 35b does not have significant binding affinities for any of 50 classical receptors, channels and transporters tested. $^{31}$ It also does not bind to either high- or lowaffinity TRH receptors. To better address potential mechanisms, we performed temporal profiling using Affymetrix microarrays. Treatment with 35 b after FPI upregulated various endogenous neuroprotective factors (BDNF, HSP 70, HIF1, mGluR7) and downregulated a number of recognized secondary injury factors (i.e., cyclins, calpains, cathepsin). ${ }^{29,32}$ These findings were confirmed by PCR and protein measurements. Particularly noteworthy were the effects of treatment on cell cycle proteins, whose upregulation is associated with neuronal apoptosis, astrogliosis, and microglial activation after TBI or SCI. ${ }^{33,34}$ Administration of $35 \mathrm{~b}$ suppressed expression of the major upstream cell cycle proteins including cyclin $\mathrm{D} 1$, the retinoblastoma protein $\mathrm{Rb}$, and E2F5. ${ }^{29}$

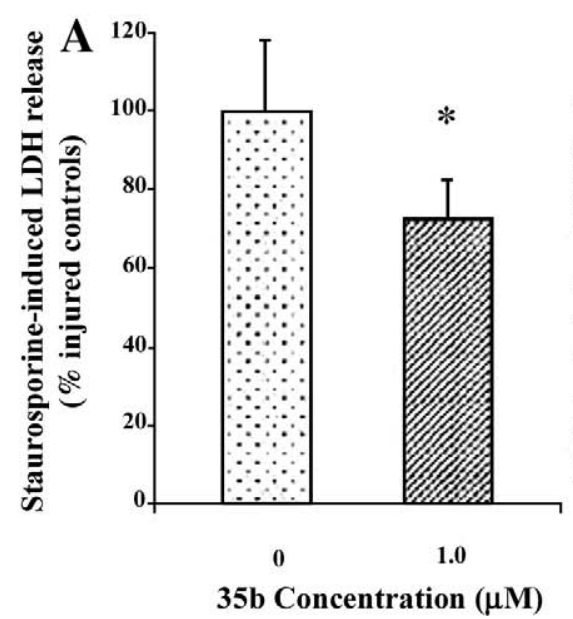

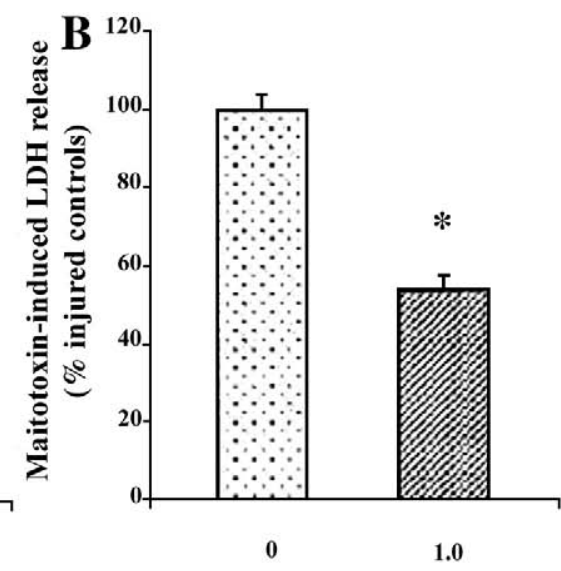

35b Concentration $(\mu \mathrm{M})$

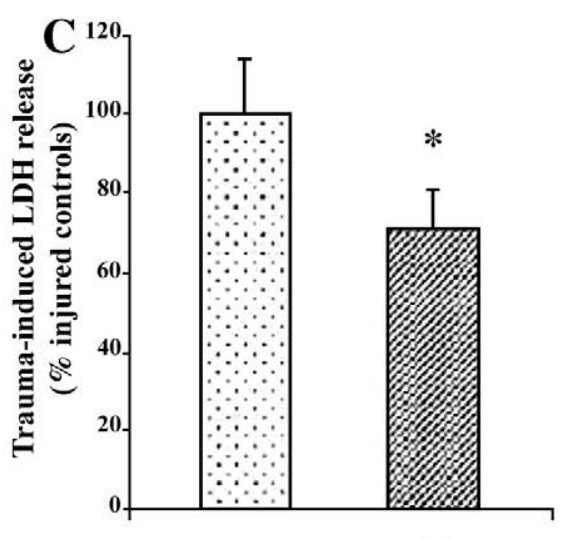

0

1.0

35b Concentration $(\mu M)$

FIG. 4. Effect of $35 \mathrm{~b}$ on lactate dehydrogenase $(\mathrm{LDH})$ release in three different in vitro models of cell death: (A) apoptotic death induced by staurosporine; (B) necrotic death induced by maitotoxin; (C) traumatic death induced by a punch model that produces both initial physical disruption and later secondary death. Bars represent means and standard deviations for LDH released 16 to $18 \mathrm{~h}$ after injury in untreated injured cultures (dots) or injured cultures treated with $35 \mathrm{~b}$ (diagonal lines) ( $\mathrm{n}=25$ to 30 wells per condition). In (A), cultures were incubated with $0.3-\mu \mathrm{mol} / \mathrm{L}$ staurosporine for 16 to $18 \mathrm{~h}$ in the presence or absence of $35 \mathrm{~b}$. In $(\mathrm{B})$, cultures were incubated with $0.1-\mathrm{nmol} / \mathrm{L}$ maitotoxin for $1 \mathrm{~h}$ in the presence or absence of $35 \mathrm{~b}$. Cultures were then washed and incubated for 16 to $18 \mathrm{~h}$ with or without $35 \mathrm{~b}$, as appropriate. In (C), 35b or media vehicle was present for 30 min before injury. Cells were then injured with a mechanical punch that delivered 28 parallel, uniformly distributed cuts to the surface of the cell layer. Thirty min after injury, cultures were washed again and incubated with $35 \mathrm{~b}$ or vehicle, as appropriate, for 16 to $18 \mathrm{~h}$. Reprinted from Faden et al. J Cereb Blood Flow Metab 2003;23: 342-354. 
A

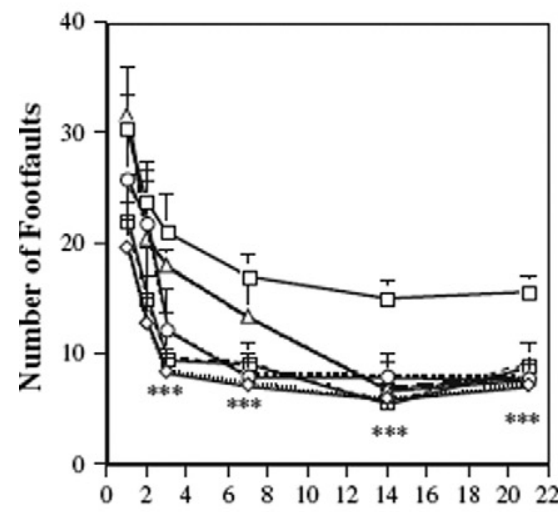

Days after Injury
B

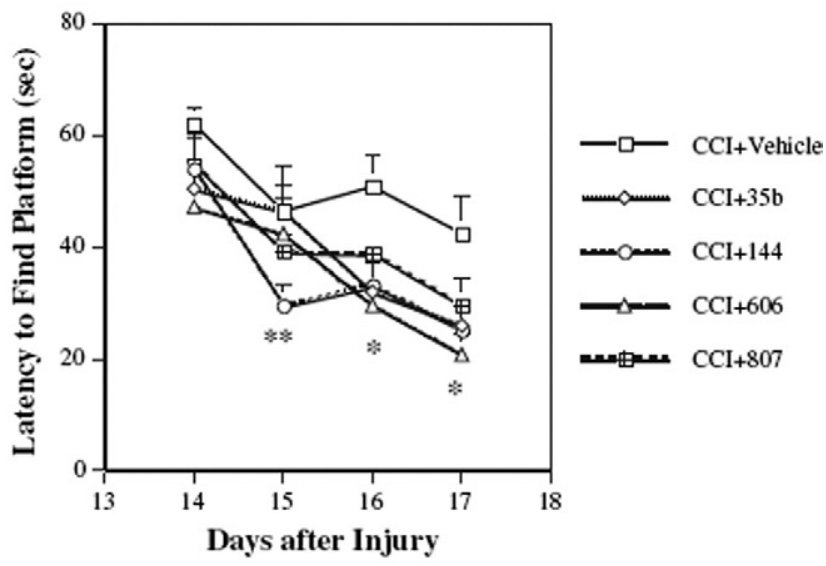

FIG. 5. A: Comparison of effects of diketopiperazines 35b, 144, 606, and 807 on motor function measured by beam walk test at 1 , 2 , $3,7,14$, and 21 days post-trauma. All diketopiperazines significantly $(p<0.001)$ improved motor function at 14 and 21 days after injury, compared with vehicle-treated injured animals. 35b, 144, and 807 also showed significant $(p<0.001)$ protection at 3 and 7 days ${ }^{* \star \star} p<0.001$ versus vehicle-treated injured (controlled cortical injury [CCl] + vehicle) animals. B: Water maze cognitive score after $\mathrm{CCl}$ in mice measured at 14, 15, 16, and 17 days post-injury. Diketopiperazines 35b, 144, 606 and 807 significantly $(p<0.05)$ improved cognitive function at 16 and 17 days after injury compared with vehicle-treated injured mice. ${ }^{*} p<0.05$ and ${ }^{* *} p<0.01$ versus vehicle-treated injured ( $\mathrm{CCl}+$ vehicle) animals. Reprinted from Faden et al. Neuropharmacology 2005;49:410-424.
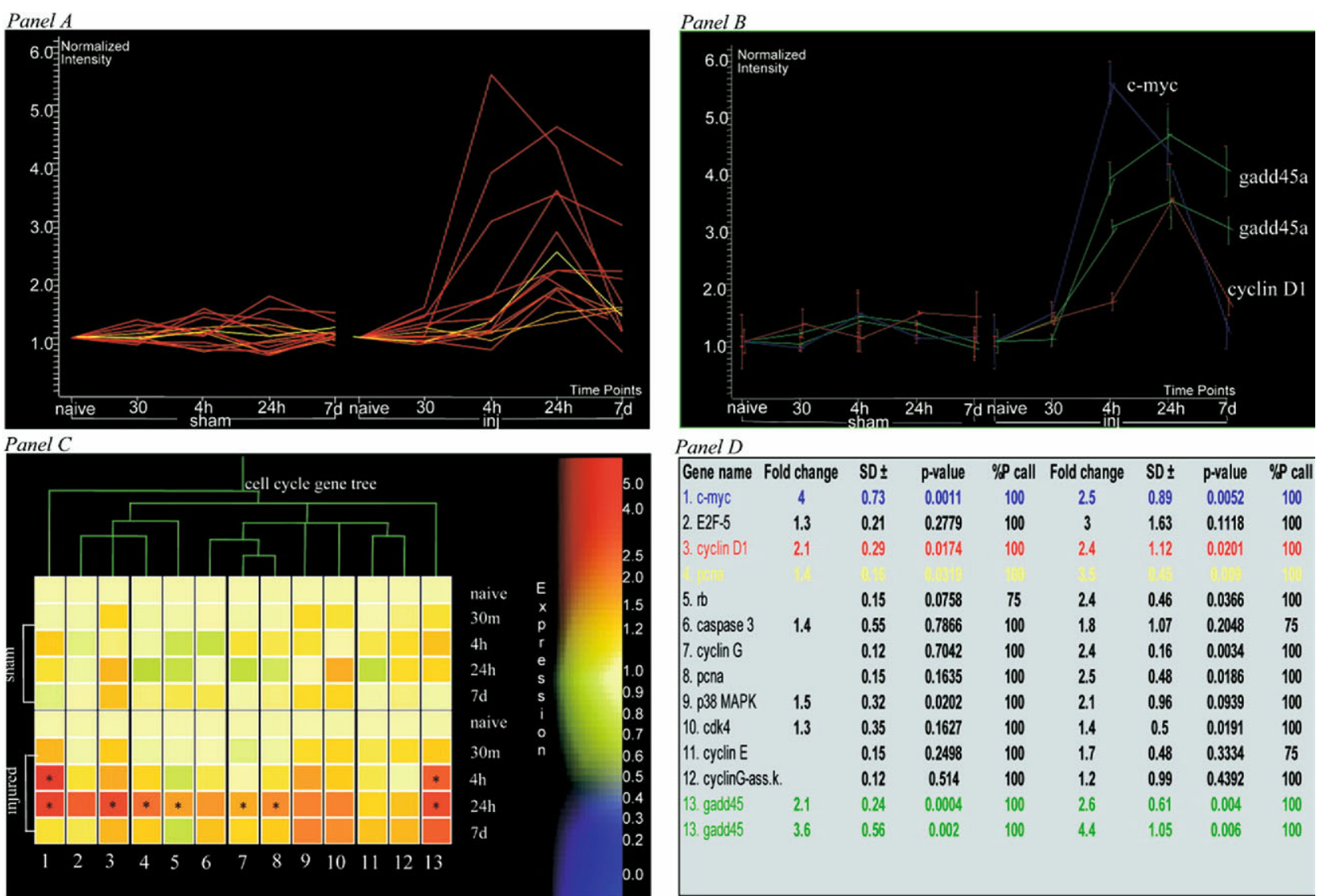

Panel $D$
\begin{tabular}{|lcccccccc|}
\hline Gene name & Fold change & SD \pm & p-value & \%P call & Fold change & SD \pm & p-value & \% call \\
1. c-myc & 4 & 0.73 & 0.0011 & 100 & 2.5 & 0.89 & 0.0052 & 100 \\
2. E2F-5 & 1.3 & 0.21 & 0.2779 & 100 & 3 & 1.63 & 0.1118 & 100 \\
3. cyclin D1 & 2.1 & 0.29 & 0.0174 & 100 & 2.4 & 1.12 & 0.0201 & 100 \\
& & & & & & & & \\
5. ib & & 0.15 & 0.0758 & 75 & 2.4 & 0.46 & 0.0366 & 100 \\
6. caspase 3 & 1.4 & 0.55 & 0.7866 & 100 & 1.8 & 1.07 & 0.2048 & 75 \\
7. cyclin G & & 0.12 & 0.7042 & 100 & 2.4 & 0.16 & 0.0034 & 100 \\
8. pcna & & 0.15 & 0.1635 & 100 & 2.5 & 0.48 & 0.0186 & 100 \\
9. p38 MAPK & 1.5 & 0.32 & 0.0202 & 100 & 2.1 & 0.96 & 0.0939 & 100 \\
10. cok4 & 1.3 & 0.35 & 0.1627 & 100 & 1.4 & 0.5 & 0.0191 & 100 \\
11. cyclin E & & 0.15 & 0.2498 & 100 & 1.7 & 0.48 & 0.3334 & 75 \\
12. cyclinG-ass.k. & 0.12 & 0.514 & 100 & 1.2 & 0.99 & 0.4392 & 100 \\
13. gadd45 & 2.1 & 0.24 & 0.0004 & 100 & 2.6 & 0.61 & 0.004 & 100 \\
13. gadd45 & 3.6 & 0.56 & 0.002 & 100 & 4.4 & 1.05 & 0.006 & 100 \\
& & & & & & & & \\
& & & & & & & & \\
\hline
\end{tabular}

FIG. 6. Functional clustering of cell cycle genes shows high expression 4 to $24 \mathrm{~h}$ after injury. Functional clustering of genes based on involvement in cell cycle progression and apoptosis. Genes of this functional cluster also belong to smaller temporal clusters (gadd45a showed temporal clustering with c-myc [R2 = 0.99]), whereas PCNA, cyclin D1, cyclin G, Rb, and E2F5 belonged to the same temporal cluster $[R 2=0.99])$. Data for all cluster members are shown in panels $(A),(C)$, and $(D)$, whereas data with standard deviations for multiple animals are shown in (B). B: Shows a self-organizing map graph subcluster applied to the cell cycle gene cluster shown in (A). Those genes showing significant $p$ values $(>0.05)$ and fold changes (twofold) between sham and injured time points are indicated with an asterisk in (C). Reprinted from Di Giovanni et al. Ann Neurol 2003;53(4):454-468. 
Various other cyclic dipeptides reduce lesion volume and improve behavioral outcome after CCI in mice with effects that are similar to those of 35 b (FIG. 5). ${ }^{29}$ In compound 606 the histidine moiety was replaced by 3,5-di-tert-butyltyrosine (DBT), a phenolic amino acid that can trap reactive oxygen species. In contrast to $35 \mathrm{~b}, 606$ blocked free radical-mediated cell death in neuronal cultures induced by FeSO4. Compound 144 also showed substantial neuroprotective actions in vitro and was highly protective in both the FPI and CCI models (FIG. 5). ${ }^{29}$

\section{CELL CYCLE GENE AND PROTEIN EXPRESSION AFTER TBI OR SCI}

Progression through the cell cycle is carefully regulated through the interplay of a number of cell cycle related proteins, including cyclins, cyclin-dependent kinases (CDKs) and CDK inhibitors. Early events include the synthesis of cyclin D, which binds to CDK4 and CDK6; in the nucleus, CDK4/6 phosphorylate the retinoblastoma protein $(\mathrm{Rb})$, leading to release of E2F tran- scription factors and transition to G1. ${ }^{35,36}$ Apoptosis and cell cycle pathways share several common regulatory elements, including the retinoblastoma protein $(\mathrm{Rb})$, E2F, and p53.

From extensive temporal profiling studies of gene expression changes after rodent $\mathrm{SCI},{ }^{37,38}$ we identified a cluster of cell cycle genes that were coordinately regulated with the oncogene $c$-myc, which has been linked to neuronal cell death. ${ }^{37,39}$ These gene expression changes, detected using Affymetrix chips (FIG. 6), were confirmed using RT-PCR, Western blots and immunocytochemistry. ${ }^{34,37,38}$ Importantly, upregulated cell cycle proteins include key upstream regulatory elements that lead to G1 transition, including cyclin D1, Rb, and E2F5. Injury is also associated with downregulation of endogenous cell cycle inhibitors such as p27.

It is known that upregulation of cell cycle proteins in post-mitotic cells, such as neurons or oligodendroglial, results in caspase-mediated cell death. ${ }^{40}$ Consistent with this view, we found that increased cell cycle expression a

Vehicle-TBI
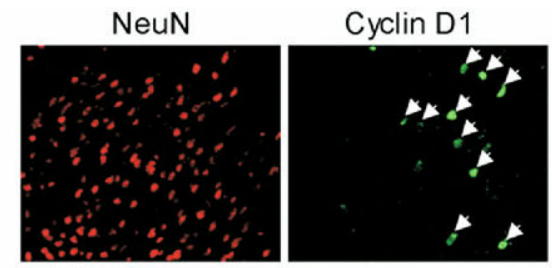

Flavopiridol-TBI
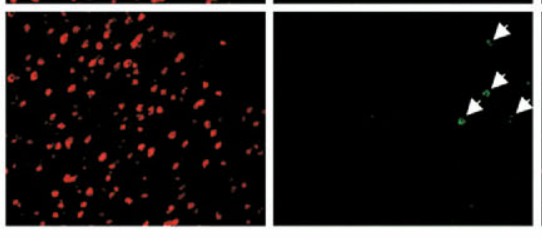

b

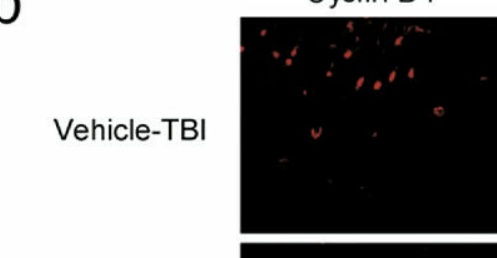

Flavopiridol-TBI

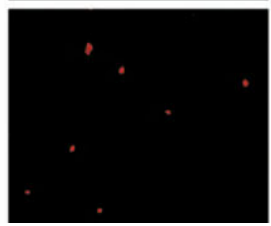

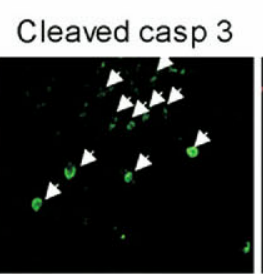

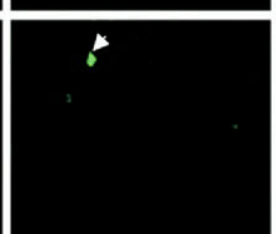

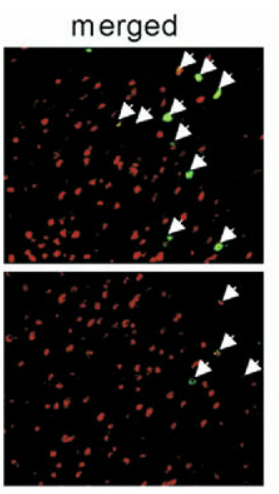

merged

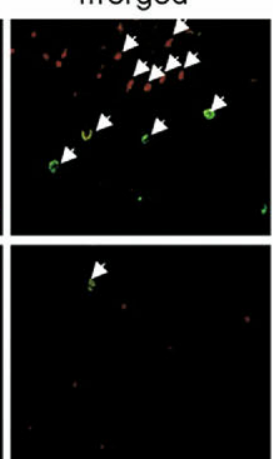

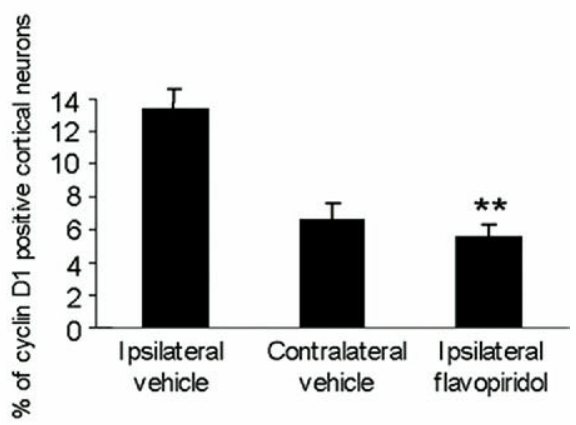

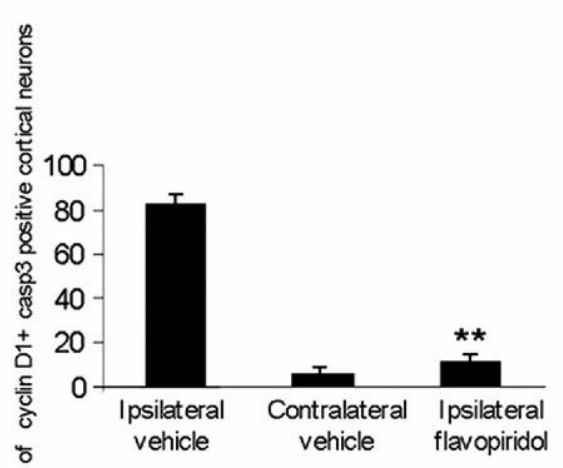

FIG. 7. Immunofluorescence shows the expression of cyclin D1 and active caspase 3 in cortical neurons after traumatic brain injury (TBI), and effects of flavopiridol treatment. a: Double immunofluorescence in coronal sections of the brain cortex around the injury site shows staining for cyclin D1 in vehicle, and flavopiridol-treated animal after TBI and for the neuronal marker NeuN. Cyclin D1 expression is induced in cortical neurons after TBI and strongly reduced after flavopiridol compared with vehicle (arrows). (Original magnification, $\times 125$.) Bar graphs show quantitation of cortical neurons expressing cyclin D1 in ipsilateral and contralateral cortex in vehicle-treated rats compared with flavopiridol (ipsilateral) $\left(^{* \star}, p<0.01\right)$. b: Double immunofluorescence in coronal sections of the brain cortex around the injury site shows staining for cyclin D1 in vehicle, and flavopiridol-treated animal after TBI, and for active caspase 3 . Flavopiridol strongly reduces cyclin D1-positive and active caspase 3-positive neurons (arrows). (Original magnification, $\times 125$.) Bar graphs show quantitation of cortical neurons co-expressing cyclin D1 and cleaved caspase 3 in ipsilateral and contralateral cortex in vehicle-treated rats compared with flavopiridol (ipsilateral) ( $\left.{ }^{* \star}, P<0.01\right)$. Reprinted from Di Giovanni S, et al. Cell cycle inhibition provides neuroprotection and reduces glial proliferation and scar formation after traumatic brain injury. Proc Natl Acad Sci U S A 2005;102:8333-8338. 
in neurons was associated with active caspase 3 expression and/or TUNEL positive staining after TBI ${ }^{33,40}$ or $\mathrm{SCI}^{37}$ (FIG. 7). Upregulation of cell cycle proteins is also readily observed in primary neuronal culture models af-
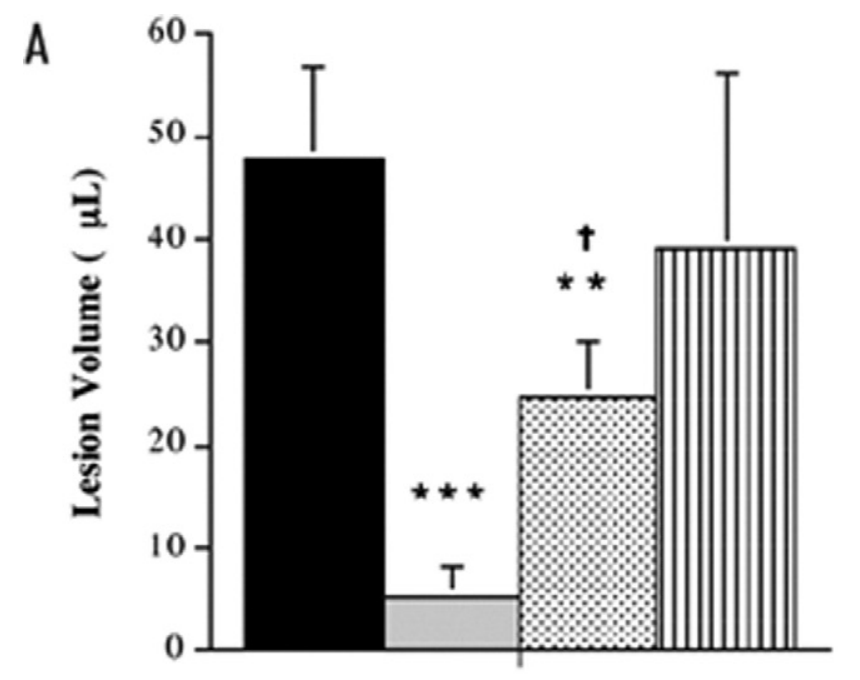

Groups ter stimulation of caspase-dependent apoptosis with ceramide, ${ }^{41} \beta$-amyloid, ${ }^{42} \mathrm{KCl}$ withdrawal, ${ }^{43}$ or DNA damage. ${ }^{44-46}$ In addition, kainic acid-induced excitotoxicity of cerebellar granule cells is associated with increased

LFP+Vehicle

$\square \mathrm{LFP}+30 \mathrm{~min}+250 \mu \mathrm{mol} / \mathrm{L}$

. $\mathrm{LFP}+4 \mathrm{~h}+250 \mu \mathrm{mol} / \mathrm{L}$

띠 LFP+30 $\mathrm{min}+100 \mu \mathrm{mol} / \mathrm{L}$

$* * \mathrm{p}<0.01$

$* * * \mathrm{p}<0.001$ vs. Vehicle

$\dagger \mathrm{p}<0.05$ vs. $250 \mu \mathrm{m} / \mathrm{L}$ Flavo given at $30 \mathrm{~min}$ post-trauma

\section{B LFP + icv Vehicle}

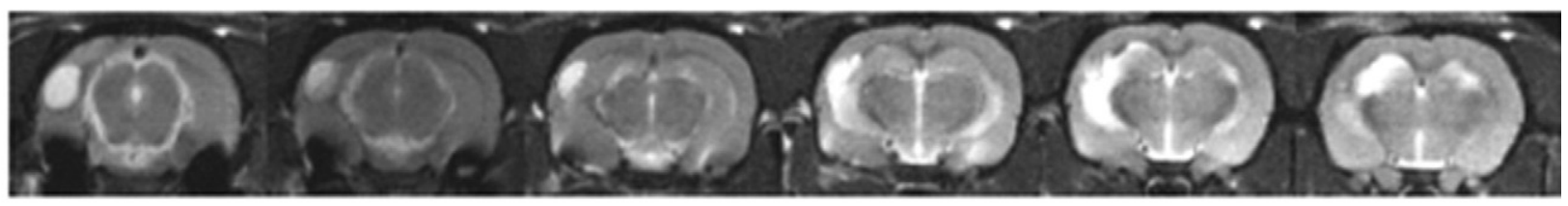

\section{LFP+30 min+icv $250 \mu \mathrm{molL}$ Flavo}

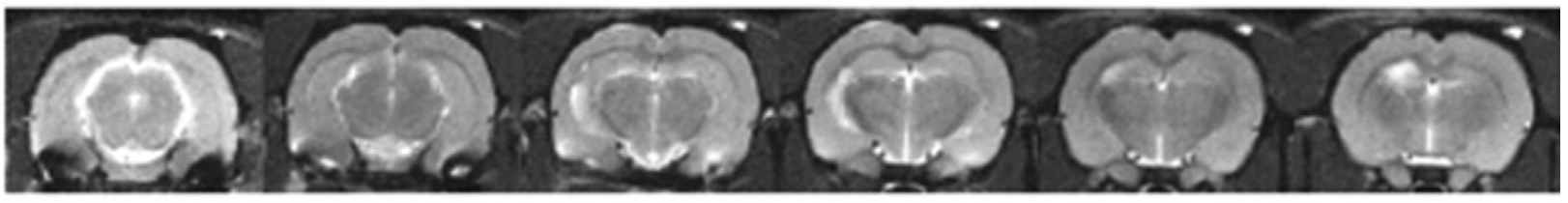

\section{LFP+4 h+icv $250 \mu \mathrm{moHL}$ Flavo}

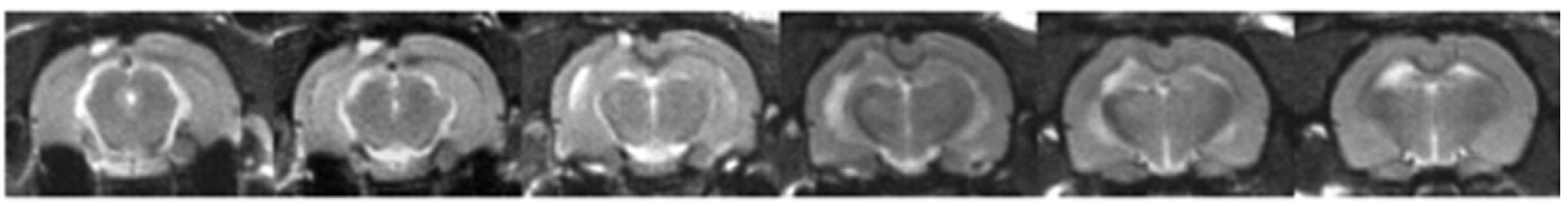

\section{LFP+30 min+icv $100 \mu$ molL Flavo}

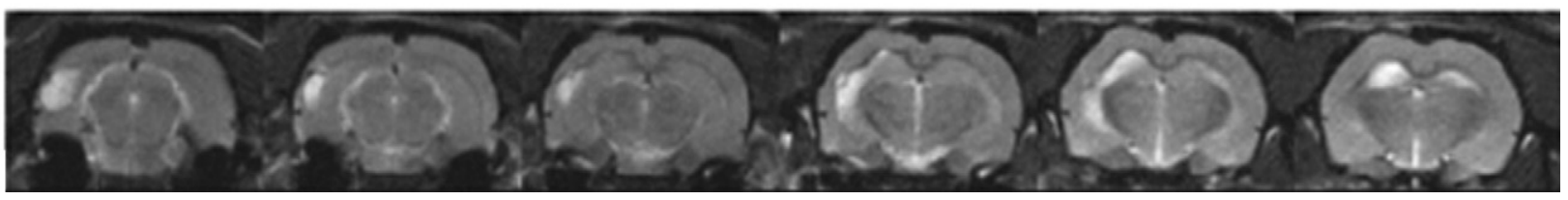

FIG. 8. Effect of flavopiridol on lateral fluid percussion (LFP)-induced lesion volume 21 days after injury in the rat. Data are from rats treated $30 \mathrm{~min}$ or $4 \mathrm{~h}$ after injury with flavopiridol $(5 \mu \mathrm{L}$ of 100 or $250 \mu \mathrm{mol} / \mathrm{L}$ solution for $5 \mathrm{~min})$ or vehicle. A: Lesion volumes $(\mathrm{n}=12$ mean \pm standard error of the mean). B: representative T2-weighted MRI of vehicle or flavopiridol-treated rats. Regions of marked hyperintensity are evident in the cortex and hippocampus. ${ }^{\star *} p<0.001$. ${ }^{\star \star *} p<0.0001$. Reprinted from Cernak I, et al. Role of the cell cycle in the pathobiology of central nervous system trauma. Cell Cycle 2005;4:1286-1293. 
expression of cyclins D and E, PCNA and E2F1, as well as with increased expression of caspases 3 and 9. ${ }^{47} \mathrm{Sim}-$ ilarly, trophic withdrawal-induced cell death is associated with increased expression of both cyclins and cyclin-dependent kinases. ${ }^{48}$

SCI and TBI cause active astrogliosis that causes glial scar formation and proliferation/activation of microglia. After injury, cell cycle proteins are highly expressed in GFAP positive cells, as well as in activated microglia. For example, cyclin D1 expression is found to be increased in microglia after transient forebrain ischemia in the rat $^{49}$ and global ischemia in the gerbil. ${ }^{50}$ Astrocyte proliferation was also associated with increased cell cycle proteins after ischemia. ${ }^{50}$ After SCI, microglia and astrocytes demonstrate a marked reduction in p27, an endogenous cell cycle inhibitor. ${ }^{51}$ Upregulation of cell cycle proteins is observed in primary cell culture models, including astroglial proliferation after exposure to serum ${ }^{52}$ or microglial proliferation/ activation after exposure to lipopolysaccharide (LPS). ${ }^{53}$ After CNS injury, astrocytes undergo rapid proliferation and contribute to the formation of the glial scar. ${ }^{54}$ This scar may

A

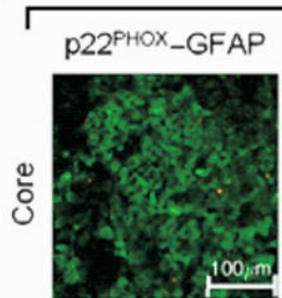

Vehicle
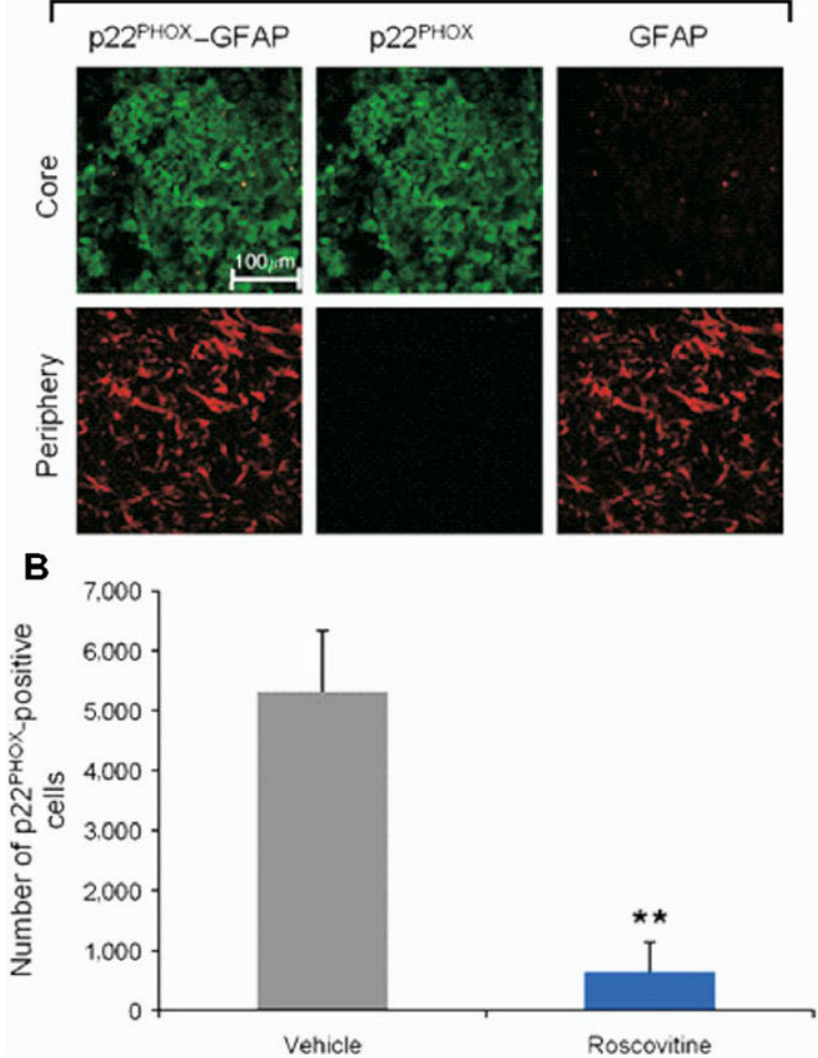

provide a physical barrier to axonal growth, ${ }^{55}$ as well as a "wall" to prevent migration of inflammatory cells into undamaged tissue. ${ }^{56,57}$ Microglia, the primary immunological cell in the CNS, undergo rapid proliferation and transition from a resting, ramified phenotype to an ameboid phagocytic phenotype that is nearly indistinguishable from infiltrating macrophages. ${ }^{58}$ Activated microglia produce proinflammatory molecules, such as interleukin (IL)-1 $\beta$, IL6, inducible nitric oxide synthase, ${ }^{59}$ complement components, ${ }^{60}$ and reactive oxygen species, ${ }^{61}$ which serve to modify both secondary injury and endogenous neuroprotective responses.

Increases in cell cycle protein expression have also been reported in chronic neurodegenerative disorders. For example, both neurons and glia show increased PCNA and cyclin D expression in human Alzheimer's patients. ${ }^{62,63}$ Furthermore, DNA replication has been identified in apoptotic neurons in human Alzheimer's patients. ${ }^{64}$ In an animal model of Alzheimer's disease, genetic APP23 mice demonstrate an increase of cell cycle related proteins in astrocytes. ${ }^{65}$
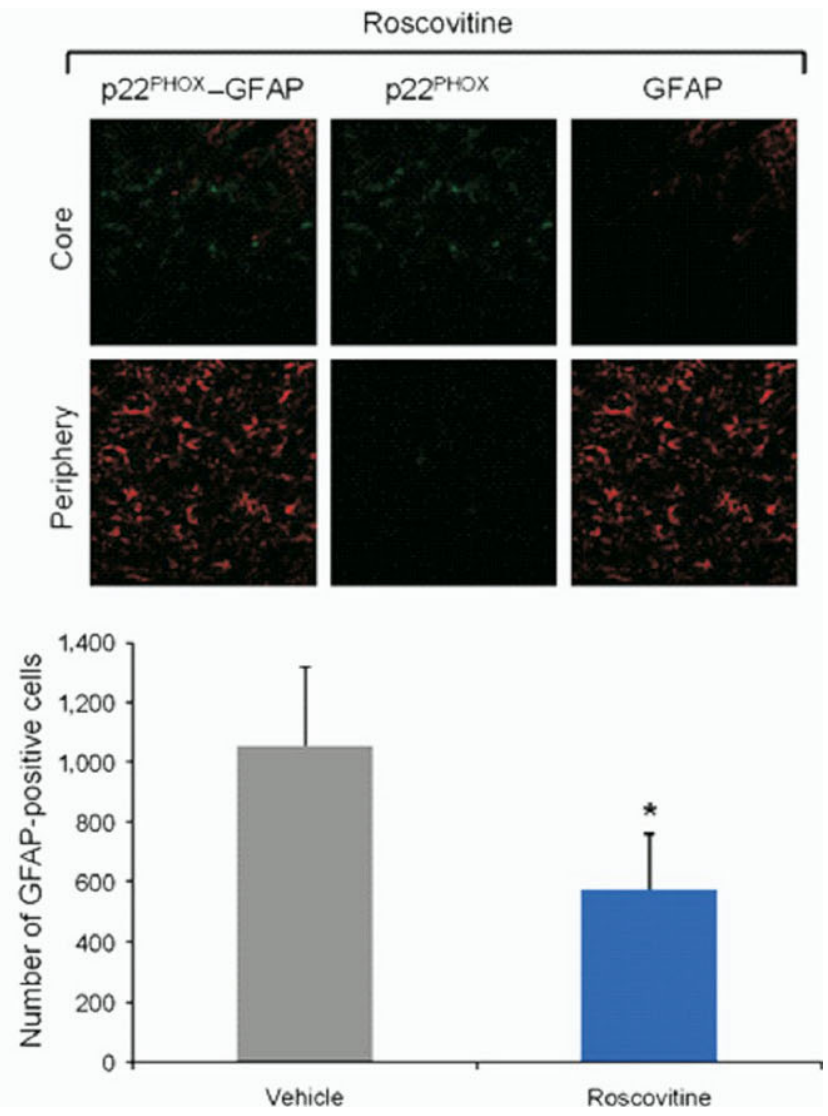

FIG. 9. Roscovitine treatment decreases activation of microglia and astroglia at 7 days after injury, as indicated by immunostaining for p22PHOX and GFAP. A: Representative composite confocal images after double-immunostaining for GFAP (red) and p22PHOX (green) of the core and periphery of the injury show that injury-dependent increase in the number of p22PHOX-positive microglia is concentrated in the core, whereas the increase in GFAP-positive astroglia occurs especially in the periphery of the lesion. Roscovitine attenuated both changes. There is no colocalization between markers for microglia and astroglia. Images showing the separate p22PHOX and GFAP channels are included. B: Cell counting indicates that roscovitine treatment results in a significant decrease in both p22PHOX ( $\mathrm{n}=3$ sections, threshold $=50$, unpaired $t$-test, $\left.{ }^{* *} p=0.0029\right)$ and GFAP-positive cells $(\mathrm{n}=3$ sections, threshold $=150$, unpaired $t$-test, $\left.{ }^{*} p=0.0298\right)$ per brain section. Reprinted from Hilton et al. J Cereb Blood Flow Metab 2008;(advance online publication). 


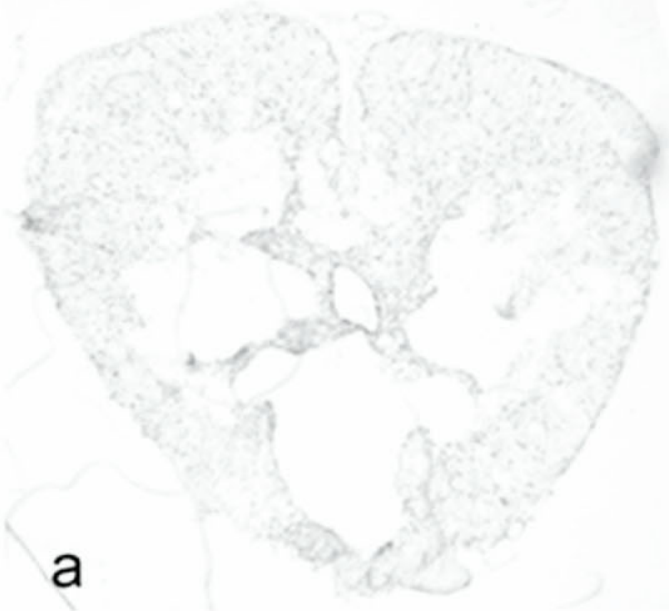

Lesion Volume

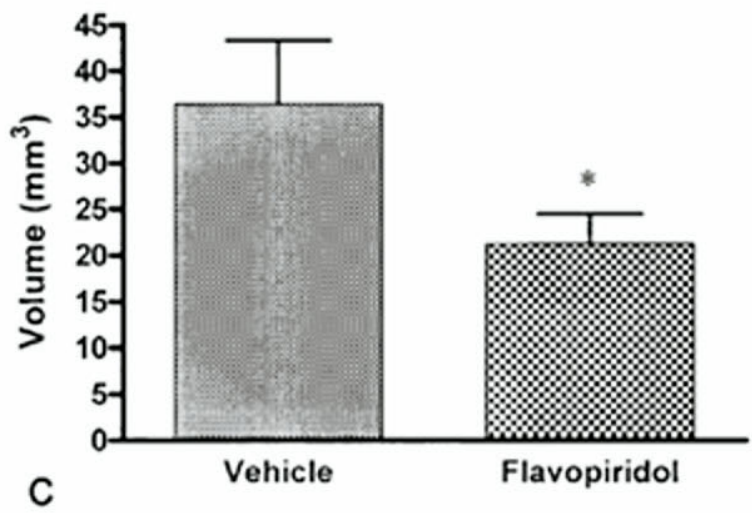

MRI vs. Histology

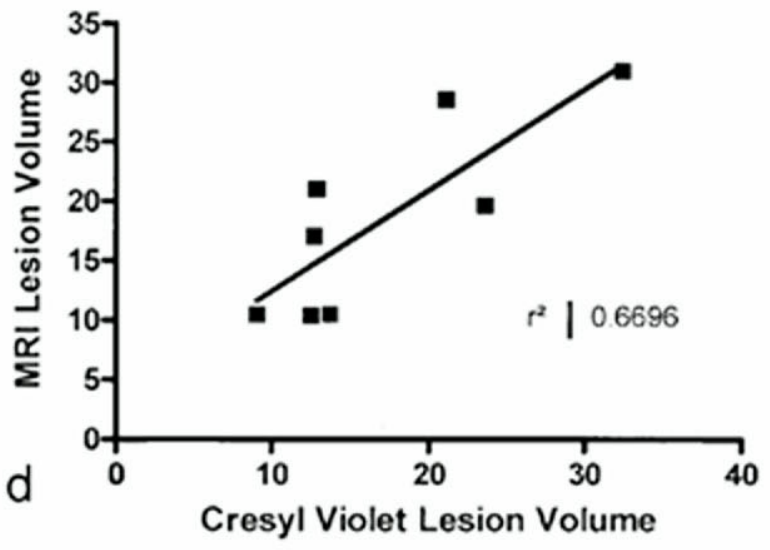

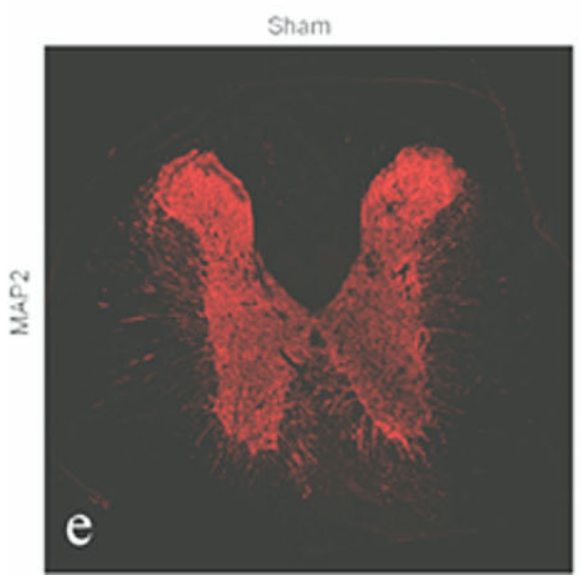
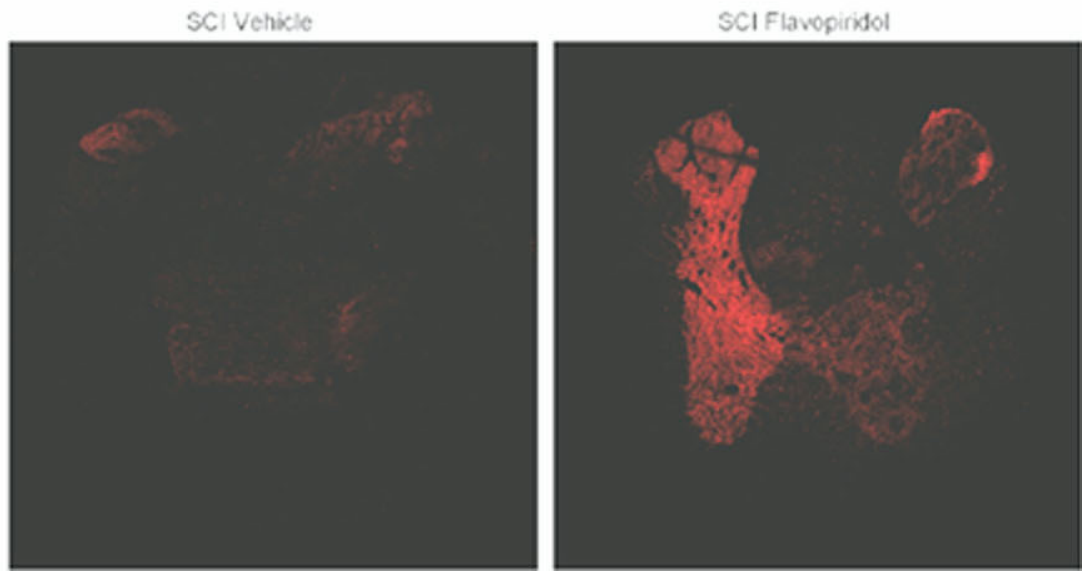

FIG. 10. Cresyl violet staining of tissue sections from flavopiridol- or vehicle-treated spinal cords. Images are taken from the center of the lesion site for both vehicle-treated (a) and flavopiridol-treated (b) samples, and demonstrate a clear decrease in tissue loss with flavopiridol treatment. Cavalieri volume estimation was performed to assess lesion volume (c). Analysis of correlation between MRI obtained lesion volume and histologically measured lesion volume shows a statistically significant correlation ( $\mathrm{r} 2=0.6696 ; p<0.05$; (d) wide-field high-resolution confocal images of a complete transversal section of the injured spinal cord, and (e) demonstrates that MAP2 expression is diminished throughout the cord at $24 \mathrm{~h}$ after spinal cord injury (SCl). This is attenuated by treatment with flavopiridol. Bar $=500 \mu \mathrm{m}$. Reprinted from Byrnes KR, et al. Cell cycle activation contributes to post-mitotic cell death and secondary damage after spinal cord injury. Brain 2007;130:2977-2992. By permission of Oxford University Press. 

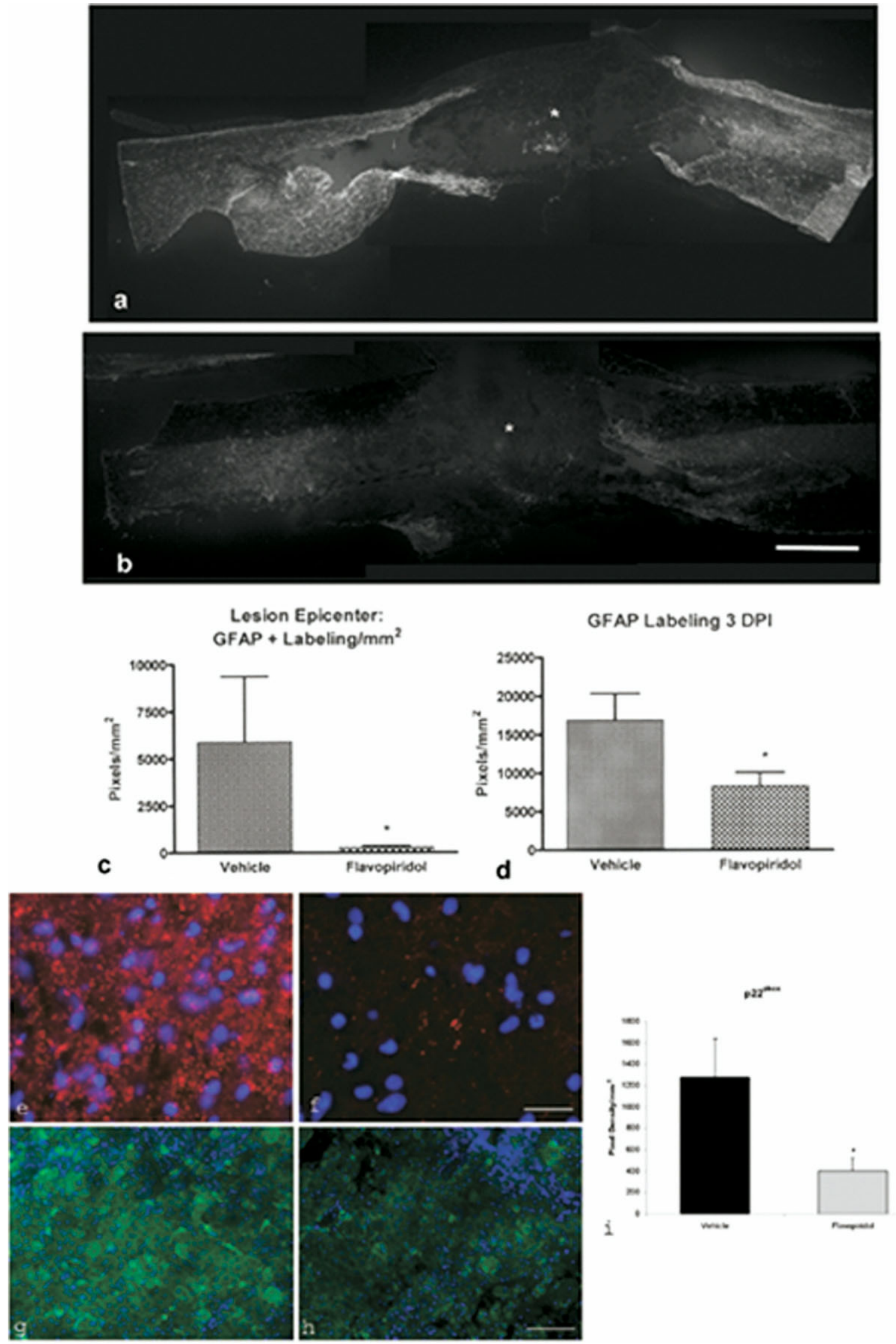


\section{INHIBITION OF CELL CYCLE}

Cell cycle inhibitors have been developed and extensively evaluated in experimental cancer models, and several have been tested in humans. The best characterized and studied among these are flavopiridol, a semi-synthetic flavonoid derived from rohitukin bark, ${ }^{66}$ and the purine analogues roscovitine and olomoucine. ${ }^{67}$ Flavopiridol blocks all the CDKs and also inhibits the transcription of cyclin D1. ${ }^{68,69}$ In contrast, the purine analogues preferentially inhibit CDK2 and CDK5, although at higher concentrations these may inhibit other kinases. ${ }^{70}$

Each of these agents shows neuroprotection in vitro, such as against etoposide-induced neuronal apoptosis ${ }^{33}$ or apoptosis of cerebellar granule cells after $\mathrm{KCl}$ withdrawal. ${ }^{43}$ Moreover, olomoucine inhibits hypoxia-induced neuronal cell death in culture, ${ }^{71}$ whereas flavopiridol inhibits kainite-mediated or colchicines-mediated apoptotic cell death. ${ }^{72,73}$ A recent study in our laboratory determined that inhibition of multiple cyclin-dependent kinases reduces etoposide-induced neuronal apoptosis, including CDK1 and CDK4. ${ }^{74}$

Cell cycle inhibitors show inhibitory effects on the proliferation and activation of mitotic cells, such as microglia and astrocytes in vitro. For example, stimulation of microglia with LPS induces proliferation. Pre-treatment of microglia with cell cycle inhibitors, such as flavopiridol or roscovitine, for $1 \mathrm{~h}$ prior to the addition of LPS results in a significant suppression of microglial proliferation $^{33}$ and nitric oxide production. ${ }^{74}$ Importantly, roscovitine treatment of microglial cells stimulated with LPS reduced microglial-induced neurotoxicity. ${ }^{74}$ Similarly, proliferation of astrocytes induced by the addition of $10 \%$ serum was completely inhibited by flavopiridol. ${ }^{33}$

In vivo, cell cycle inhibition using pharmacological approaches has shown neuroprotective effects. For example, early treatment with flavopiridol, administered centrally, showed remarkable neuroprotection after FPI in rats. ${ }^{40}$ Lesion volume was reduced by approximately $70 \%$ and chronic behavioral recovery (motor and cognitive) was indistinguishable from sham-injured controls. Caspase-mediated neuronal cell death after TBI was nearly completely attenuated. In addition to neuroprotection, significant effects on mitotic cells were also observed. GFAP expression and markers of microglial activation were markedly reduced. These changes were associated with near complete suppression of cell cycle proteins in neurons, astroglia, and microglia, respectively. ${ }^{40}$ Delayed administration of flavopiridol was similarly found to have neuroprotective effects. In a follow-up study, flavopiridol was administered centrally at $30 \mathrm{~min}$ or $4 \mathrm{~h}$ after FPI, or systemically (intraperitoneally) at $24 \mathrm{~h}$ after FPI; ${ }^{33}$ each of these treatments resulted in markedly reduced lesion volumes that were approximately $90 \%, 50 \%$, and $60 \%$, respectively (FIG. 8).

The more specific cell cycle inhibitor roscovitine, which does not have potentially confusing effects on gene transcription, has similar actions after FPI. Administration of roscovitine $30 \mathrm{~min}$ after FPI resulted in highly significant reductions in lesion volume and improved behavioral outcome (motor and cognitive). This cell cycle inhibitor also reduced astrogliosis and produced a marked inhibition of microglial activation-related inflammation ${ }^{74}$ (FIG. 9).

Research in SCI confirms the strong beneficial effects of treatment with cell cycle inhibitors. We have shown that flavopiridol treatment, centrally administered by mini-osmotic pump beginning $30 \mathrm{~min}$ post-trauma and continuing over 7 days, significantly improved motor recovery and reduced lesion volume at 28 days. ${ }^{34}$ Treatment-reduced cell cycle protein induction in neurons and astrocytes; this reduction was associated with decreased cleaved caspase-3 labeling in neurons and oligodendrocytes, as well as reduction in glial scar. Neuronal loss, measured by MAP-2 staining, was alleviated by flavopiridol treatment, and tissue loss was significantly reduced overall. Further treatment with the cell-cycle inhibitor markedly limited microglial activation and associated inflammatory factors (FIGS. 10 and 11). The cell cycle inhibitor olomoucine has also been shown to decrease lesion volume and improve function after $\mathrm{SCI}^{75}$ Reductions in microglial-related inflammation ${ }^{76}$ and astrocytic $\mathrm{scar}^{75}$ were found with olomoucine treatment, supporting the beneficial effect of cell-cycle inhibition after SCI. Preliminary work using cyclin D1

\footnotetext{
FIG. 11. Astrocyte and microglial marker immunohistochemistry after injury and treatment. Immunohistochemistry performed for astrocytes $(a, b)$, osteopontin $(e, f)$, and p22phox $(g, h)$ at 3 and 28 days post-injury. Heavy astrocytic (GFAP) labeling was found surrounding the lesion site $\left(^{*}\right)$ at 28 days after $\mathrm{SCl}$ in vehicle-treated tissue (shown as a mosaic image of the entire 10 -mm cord section surrounding the lesion epicenter); (a) however, little GFAP labeling was found in samples that had received flavopiridol continuous infusion (b). Quantitation of the proportional area of GFAP labeling in the spinal cord (through the $1 \mathrm{~cm}$ surrounding the lesion site) showed a significant decrease in GFAP labeling at 28 (c) and 3 (d) days post-injury in flavopiridol-treated tissue $(p<0.05 ; n=3 / g r o u p$ at 3 rd day; 10 /group at 28 days). Immunolabeling for osteopontin and p22phox, factors expressed by microglia, was also decreased by flavopiridol treatment $(f, h)$ in comparison to vehicle $(e, g)$. All images are obtained from $1 \mathrm{~mm}$ rostral to the lesion epicenter, in the center region of a transverse spinal cord section. Quantitation of p22phox labeling in the spinal cord (through the $1 \mathrm{~cm}$ surrounding the lesion site) showed a significant decrease in labeling at 28 days post-injury in flavopiridol-treated tissue $\left(\mathrm{i} ;{ }^{*} p<0.05\right)$. Bar $=1 \mathrm{~mm}(\mathrm{a}, \mathrm{b}) ; 50$ $\mu \mathrm{m}(\mathrm{e}, \mathrm{f}) ; 100 \mu \mathrm{m}(\mathrm{g}, \mathrm{h})$. Reprinted from Byrnes KR, et al. Cell cycle activation contributes to post-mitotic cell death and secondary damage after spinal cord injury. Brain 2007;130:2977-2992. By permission of Oxford University Press.
} 
knockout mice subjected to SCI has shown decreased lesion volumes in knockouts as compared to wild type controls, consistent with the pharmacological inhibition studies. ${ }^{34}$

Research in experimental cerebral ischemia is highly consistent with the TBI and SCI studies. Dominant negative CDK4/5 animals show reduced neuronal cell death after focal or global brain ischemia, ${ }^{77}$ as does treatment with CDK inhibitors. ${ }^{78,79}$ Moreover, after focal cerebral ischemia, cyclin D1 knockouts or animals treated with olomoucine show reduced astrocyte proliferation. Excitotoxic cell death after kainic acid administration is attenuated by treatment with anti-sense oligonucleotides directed against CDK4 or cyclin D1.

\section{SUMMARY}

Activation of cell cycle proteins in the CNS causes proliferation of mitotic cells, such as astroglia or microglia, but induces apoptosis in post-mitotic cells, such as neurons or oligodendroglia. Acute injuries to the CNS, including TBI and SCI, cause upregulation of many cellcycle proteins in both mitotic and post-mitotic cells. These changes cause neuronal and oligodendroglial cell death, astroglial scar formation and proliferation/activation of microglia, with the release of associated inflammatory factors. Treatment with cell-cycle inhibitors results in striking neuroprotection, likely related to its multifunctional actions on these diverse cell types. Because cell-cycle proteins have such diverse effects, even selective inhibitors of these pathways may serve as multifunctional neuroprotective agents.

Another approach to multi-potential drug treatment of CNS injury is to use compounds that modulate different signal transduction pathways that are involved in secondary injury. TRH is a naturally occurring brain hormone, which when used at higher than physiological levels as a drug can inhibit many factors and mechanisms implicated in delayed cell death. Thus, TRH and TRH analogues can improve blood flow and bio-energetic state; limit loss of ionic homeostasis; reduce lipid degradation; and inhibit the actions of endogenous opioids, leukotrienes, platelet-activating factor, and possibly glutamate. ${ }^{29,32}$ The neuroprotective effects do not appear to be mediated by TRH receptors, as they occur at supraphysiological doses and can be dissociated from the other physiological effects of TRH (i.e., endocrine, analeptic, autonomic).

Diketopiperazines that are structurally related to a metabolic product of TRH have marked neuroprotective activity, but do not act on either high- or low-affinity TRH receptors. They also have diverse multifunctional neuroprotective actions. As with cell-cycle inhibitors, the prototype compound $35 \mathrm{~b}$ inhibits the activation of many cell-cycle proteins after injury. But they also reduce other known secondary injury factors, including calpains and cathepsins, while upregulating several well-established endogenous neuroprotective factors including brain derived neurotrophic factor, heat shock protein 70 , and hypoxia-inducible factor 1 . Each of the latter factors has considerable protective activity in animal models. These findings underscore the attractiveness of multifunctional drug approaches for the treatment of neurotrauma and other neurodegenerative disorders.

Acknowledgments: This work has been supported by National Institutes of Health grants 5R01NS052568 and 5R01NS054221 to author (AIF).

\section{REFERENCES}

1. Yakovlev AG, Faden AI. Mechanisms of neural cell death: implications for development of neuroprotective treatment strategies. NeuroRX 2004;1:5-16.

2. Faden AI, Stoica B. Neuroprotection: challenges and opportunities. Arch Neurol 2007;64:794-800.

3. Faden AI. Neuroprotection and traumatic brain injury: theoretical option or realistic proposition. Curr Opin Neurol 2002;15:707712.

4. Dumont RJ, Okonkwo DO, Verma S, et al. Acute spinal cord injury, part I: pathophysiologic mechanisms. Clin Neuropharmacol 2001;24:254-264.

5. Tator $\mathrm{CH}$. Experimental and clinical studies of the pathophysiology and management of acute spinal cord injury. J Spinal Cord Med 1996;19:206-214.

6. Olney JW. Excitotoxin-mediated neuron death in youth and old age. Prog Brain Res 1990;86:37-51.

7. Faden AI. Comparison of single and combination drug treatment strategies in experimental brain trauma. J Neurotrauma 1993;10: 91-100.

8. Faden AI, Jacobs TP, Holaday JW. Thyrotropin-releasing hormone improves neurologic recovery after spinal trauma in cats. $\mathrm{N}$ Engl J Med 1981;305:1063-1067.

9. Faden AI, Jacobs TP, Smith MT. Thyrotropin-releasing hormone in experimental spinal injury: dose response and late treatment. Neurology 1984;34:1280-1284.

10. Faden AI, Yum SW, Lemke M, Vink R. Effects of TRH-analog treatment on tissue cations, phospholipids and energy metabolism after spinal cord injury. J Pharmacol Exp Ther 1990;255:608-614.

11. Lux WE, Jr., Feuerstein G, Faden AI. Alteration of leukotriene D4 hypotension by thyrotropin releasing hormone. Nature 1983;302: 822-824.

12. Feuerstein G, Lux WE, Ezra D, Hayes EC, Snyder F, Faden AI. Thyrotropin-releasing hormone blocks the hypotensive effects of platelet-activating factor in the unanesthetized guinea pig. J Cardiovasc Pharmacol 1985;7:335-340.

13. McIntosh TK, Vink R, Faden AI. An analogue of thyrotropinreleasing hormone improves outcome after brain injury: 31P-NMR studies. Am J Physiol 1988;254:R785-792.

14. McIntosh TK, Vink R, Faden AI. Beneficial effect of the TRH analog CG-3703 on outcome and survival following traumatic brain injury in rats. Prog Clin Biol Res 1988;264:415-420.

15. Faden AI. TRH analog YM-14673 improves outcome following traumatic brain and spinal cord injury in rats: dose-response studies. Brain Res 1989;486:228-235

16. Faden AI, Fox GB, Fan L, et al. Novel TRH analog improves motor and cognitive recovery after traumatic brain injury in rodents. Am J Physiol 1999;277:R1196-1204.

17. Faden AI, Sacksen I, Noble LJ. Structure-activity relationships of TRH analogs in rat spinal cord injury. Brain Res 1988;448:287293.

18. Wang GL, Zhu C. Effects of thyrotropin-releasing hormone on acute experimental traumatic head injury in cats. Chin Med J (Engl) 1991;104:939-944. 
19. Tanaka K, Ogawa N, Asanuma M, Kondo Y. Thyrotropin releasing hormone prevents abnormalities of cortical acetylcholine and monoamines in mice following head injury. Regul Pept 1997; 70:173-178.

20. Arias MJ. Treatment of experimental spinal cord injury with TRH, naloxone, and dexamethasone. Surg Neurol 1987;28:335-338.

21. Behrmann DL, Bresnahan JC, Beattie MS. Modeling of acute spinal cord injury in the rat: neuroprotection and enhanced recovery with methylprednisolone, U-74006F and YM-14673. Exp Neurol 1994;126:61-75.

22. Puniak MA, Freeman GM, Agresta CA, Van Newkirk L, Barone CA, Salzman SK. Comparison of a serotonin antagonist, opioid antagonist, and TRH analog for the acute treatment of experimental spinal trauma. J Neurotrauma 1991;8:193-203.

23. Pitts LH, Ross A, Chase GA, Faden AI. Treatment with thyrotropin-releasing hormone (TRH) in patients with traumatic spinal cord injuries. J Neurotrauma 1995;12:235-243.

24. Friedman TC, Wilk S. Delineation of a particulate thyrotropinreleasing hormone-degrading enzyme in rat brain by the use of specific inhibitors of prolyl endopeptidase and pyroglutamyl peptide hydrolase. J Neurochem 1986;46:1231-1239.

25. Coggins PJ, McDermott JR, Snell CR, Gibson AM. Thyrotrophin releasing hormone degradation by rat synaptosomal peptidases: production of the metabolite His-Pro. Neuropeptides 1987;10:147156.

26. Faden Knoblach SM, Movsesyan VA, Lea PMt, Cernak I. Novel neuroprotective tripeptides and dipeptides. Ann N Y Acad Sci 2005;1053:472-481.

27. Faden AI, Labroo VM, Cohen LA. Imidazole-substituted analogues of TRH limit behavioral deficits after experimental brain trauma. J Neurotrauma 1993;10:101-108.

28. Prasad C. Limited proteolysis and physiological regulation: an example from thyrotropin-releasing hormone metabolism. Thyroid 1998;8:969-975.

29. Faden AI, Movsesyan VA, Knoblach SM, Ahmed F, Cernak I. Neuroprotective effects of novel small peptides in vitro and after brain injury. Neuropharmacology 2005;49:410-424.

30. Faden AI, Fox GB, Di X, et al. Neuroprotective and nootropic actions of a novel cyclized dipeptide after controlled cortical impact injury in mice. J Cereb Blood Flow Metab 2003;23:355-363.

31. Faden AI, Knoblach SM, Cernak I, et al. Novel diketopiperazine enhances motor and cognitive recovery after traumatic brain injury in rats and shows neuroprotection in vitro and in vivo. J Cereb Blood Flow Metab 2003;23:342-354.

32. Faden AI, Knoblach SM, Movsesyan VA, Cernak I. Novel small peptides with neuroprotective and nootropic properties. J Alzheimers Dis 2004;6:S93-97.

33. Cernak I, Stoica B, Byrnes KR, Di Giovanni S, Faden AI. Role of the cell cycle in the pathobiology of central nervous system trauma. Cell Cycle 2005;4:1286-1293.

34. Byrnes KR, Stoica BA, Fricke S, Di Giovanni S, Faden AI. Cell cycle activation contributes to post-mitotic cell death and secondary damage after spinal cord injury. Brain 2007;130:2977-2992.

35. Kitagawa M, Higashi H, Jung HK, et al. The consensus motif for phosphorylation by cyclin D1-Cdk4 is different from that for phosphorylation by cyclin A/E-Cdk2. Embo J 1996;15:7060-7069.

36. Sears RC, Nevins JR. Signaling networks that link cell proliferation and cell fate. J Biol Chem 2002;277:11617-11620.

37. Di Giovanni S, Knoblach SM, Brandoli C, Aden SA, Hoffman EP, Faden AI. Gene profiling in spinal cord injury shows role of cell cycle in neuronal death. Ann Neurol 2003;53:454-468.

38. De Biase A, Knoblach SM, Di Giovanni S, et al. Gene expression profiling of experimental traumatic spinal cord injury as a function of distance from impact site and injury severity. Physiol Genomics 2005;22:368-381.

39. Kangas A, Nicholson DW, Holtta E. Involvement of CPP32/ Caspase-3 in c-Myc-induced apoptosis. Oncogene 1998;16:387398.

40. Di Giovanni S, Movsesyan V, Ahmed F, et al. Cell cycle inhibition provides neuroprotection and reduces glial proliferation and scar formation after traumatic brain injury. Proc Natl Acad Sci U S A 2005;102:8333-8338.
41. Strazza M, Luddi A, Brogi A, et al. Activation of cell cycle regulatory proteins in the apoptosis of terminally differentiated oligodendrocytes. Neurochem Res 2004;29:923-931.

42. Giovanni A, Wirtz-Brugger F, Keramaris E, Slack R, Park DS. Involvement of cell cycle elements, cyclin-dependent kinases, $\mathrm{pRb}$, and E2F x DP, in B-amyloid-induced neuronal death. J Biol Chem 1999;274:19011-19016.

43. Padmanabhan J, Park DS, Greene LA, Shelanski ML. Role of cell cycle regulatory proteins in cerebellar granule neuron apoptosis. J Neurosci 1999;19:8747-8756.

44. Otsuka Y, Tanaka T, Uchida D, et al. Roles of cyclin-dependent kinase 4 and p53 in neuronal cell death induced by doxorubicin on cerebellar granule neurons in mouse. Neurosci Lett 2004;365:180 185.

45. Kruman II, Wersto RP, Cardozo-Pelaez F, et al. Cell cycle activation linked to neuronal cell death initiated by DNA damage. Neuron 2004;41:549-561.

46. Park DS, Morris EJ, Bremner R, et al. Involvement of retinoblastoma family members and E2F/DP complexes in the death of neurons evoked by DNA damage. J Neurosci 2000;20:3104-3114.

47. Park DS, Obeidat A, Giovanni A, Greene LA. Cell cycle regulators in neuronal death evoked by excitotoxic stress: implications for neurodegeneration and its treatment. Neurobiol Aging 2000;21: 771-781.

48. Park DS, Levine B, Ferrari G, Greene LA. Cyclin dependent kinase inhibitors and dominant negative cyclin dependent kinase 4 and 6 promote survival of NGF-deprived sympathetic neurons. J Neurosci 1997; 17:8975-8983.

49. Wiessner C, Brink I, Lorenz P, Neumann-Haefelin T, Vogel P, Yamashita K. Cyclin D1 messenger RNA is induced in microglia rather than neurons following transient forebrain ischaemia. Neuroscience 1996;72:947-958.

50. Kato H, Takahashi A, Itoyama Y. Cell cycle protein expression in proliferating microglia and astrocytes following transient global cerebral ischemia in the rat. Brain Res Bull 2003;60:215-221.

51. Shen A, Liu Y, Zhao J, et al. Temporal-spatial expressions of p27kip1 and its phosphorylation on Serine-10 after acute spinal cord injury in adult rat: implications for post-traumatic glial proliferation. Neurochem Int 2008;52:1266-1275.

52. Tanaka T, Tatsuno I, Noguchi Y, et al. Activation of cyclindependent kinase $2(\mathrm{Cdk} 2)$ in growth-stimulated rat astrocytes. Geranylgeranylated Rho small GTPase(s) are essential for the induction of cyclin E gene expression. J Biol Chem 1998;273: 26772-26778.

53. Lee SC, Liu W, Brosnan CF, Dickson DW. GM-CSF promotes proliferation of human fetal and adult microglia in primary cultures. Glia 1994;12:309-318.

54. Hoke A, Silver J. Heterogeneity among astrocytes in reactive gliosis. Perspect Dev Neurobiol 1994;2:269-274.

55. Silver J, Miller JH. Regeneration beyond the glial scar. Nat Rev Neurosci 2004;5:146-156.

56. Ridet JL, Malhotra SK, Privat A, Gage FH. Reactive astrocytes: cellular and molecular cues to biological function. Trends Neurosci 1997;20:570-577.

57. Faulkner JR, Herrmann JE, Woo MJ, Tansey KE, Doan NB, Sofroniew MV. Reactive astrocytes protect tissue and preserve function after spinal cord injury. J Neurosci 2004;24:2143-2155.

58. Raivich G, Jones LL, Werner A, Bluthmann H, Doetschmann T, Kreutzberg GW. Molecular signals for glial activation: pro- and anti-inflammatory cytokines in the injured brain. Acta Neurochir Suppl 1999;73:21-30.

59. Benveniste EN. Inflammatory cytokines within the central nervous system: sources, function, and mechanism of action. Am J Physiol 1992;263:C1-16.

60. Lynch NJ, Willis CL, Nolan CC, et al. Microglial activation and increased synthesis of complement component $\mathrm{Clq}$ precedes blood-brain barrier dysfunction in rats. Mol Immunol 2004;40: 709-716.

61. Pawate S, Shen Q, Fan F, Bhat NR. Redox regulation of glial inflammatory response to lipopolysaccharide and interferongamma. J Neurosci Res 2004;77:540-551.

62. Wharton SB, Williams GH, Stoeber K, et al. Expression of Ki67, PCNA and the chromosome replication licensing protein $\mathrm{Mcm} 2$ in 
glial cells of the ageing human hippocampus increases with the burden of Alzheimer-type pathology. Neurosci Lett 2005;383: 33-38.

63. Yang Y, Mufson EJ, Herrup K. Neuronal cell death is preceded by cell cycle events at all stages of Alzheimer's disease. J Neurosci 2003;23:2557-2563.

64. Yang Y, Geldmacher DS, Herrup K. DNA replication precedes neuronal cell death in Alzheimer's disease. J Neurosci 2001;21: 2661-2668.

65. Gartner U, Bruckner MK, Krug S, Schmetsdorf S, Staufenbiel M, Arendt T. Amyloid deposition in APP23 mice is associated with the expression of cyclins in astrocytes but not in neurons. Acta Neuropathol 2003;106:535-544.

66. Newcomb EW. Flavopiridol: pleiotropic biological effects enhance its anti-cancer activity. Anticancer Drugs 2004;15:411-419.

67. Meijer L, Raymond E. Roscovitine and other purines as kinase inhibitors. From starfish oocytes to clinical trials. Acc Chem Res 2003;36:417-425.

68. Dai Y, Grant S. Small molecule inhibitors targeting cyclin-dependent kinases as anticancer agents. Curr Oncol Rep 2004;6:123-130.

69. Swanton C. Cell-cycle targeted therapies. Lancet Oncol 2004;5: 27-36.

70. Abraham RT, Acquarone M, Andersen A, et al. Cellular effects of olomoucine, an inhibitor of cyclin-dependent kinases. Biol Cell 1995;83:105-120.

71. Bossenmeyer-Pourie C, Chihab R, Schroeder H, Daval JL. Transient hypoxia may lead to neuronal proliferation in the developing mammalian brain: from apoptosis to cell cycle completion. Neuroscience 1999;91:221-231.
72. Jorda EG, Verdaguer E, Canudas AM, et al. Neuroprotective action of flavopiridol, a cyclin-dependent kinase inhibitor, in colchicineinduced apoptosis. Neuropharmacology 2003;45:672-683.

73. Verdaguer E, Jimenez A, Canudas AM, et al. Inhibition of cell cycle pathway by flavopiridol promotes survival of cerebellar granule cells after an excitotoxic treatment. J Pharmacol Exp Ther 2004;308:609-616.

74. Hilton GD, Stoica BA, Byrnes KR, Faden AI. Roscovitine reduces neuronal loss, glial activation, and neurologic deficits after brain trauma. J Cereb Blood Flow Metab 2008;28:18451859.

75. Tian DS, Yu ZY, Xie MJ, Bu BT, Witte OW, Wang W. Suppression of astroglial scar formation and enhanced axonal regeneration associated with functional recovery in a spinal cord injury rat model by the cell cycle inhibitor olomoucine. J Neurosci Res 2006;84:1053-1063.

76. Tian DS, Dong Q, Pan DJ, et al. Attenuation of astrogliosis by suppressing of microglial proliferation with the cell cycle inhibitor olomoucine in rat spinal cord injury model. Brain Res 2007;1154: 206-214.

77. Rashidian J, Iyirhiaro G, Aleyasin H, et al. Multiple cyclin-dependent kinases signals are critical mediators of ischemia/hypoxic neuronal death in vitro and in vivo. Proc Natl Acad Sci U S A 2005; 102:14080-14085.

78. Wang F, Corbett D, Osuga H, et al. Inhibition of cyclin-dependent kinases improves CA1 neuronal survival and behavioral performance after global ischemia in the rat. J Cereb Blood Flow Metab 2002;22:171-182.

79. Osuga H, Osuga S, Wang F, et al. Cyclin-dependent kinases as a therapeutic target for stroke. Proc Natl Acad Sci U S A 2000;97: $10254-10259$. 